повинні в загальнообов'язковому порядку дотримуватись згідно із законодавчим полем.

Характерними ознаками фінансових приписів $€$ категоричність, загальнообов'язковість та караність за їх недотримання. При цьому право і правову сторону фінансової й інвестиційної діяльності суспільство сприймає як певний сумарний вектор інтересів держави та соціальноекономічних груп, задіяних у цих процесах безпосередньо чи опосередковано, оскільки до сфери фінансового впливу потрапляють майнові інтереси учасників цих правовідносин.

\title{
Література:
}

1. Зюнькін А. Г. Фінансове право: опорний конспект лекцій. Київ: МАУП, 2003. $160 \mathrm{c}$.

2. Савченко Л. А., Цимбалюк А. В., Шкарупа В. К., Глух М. В. Фінансове право: навч. посіб. Ірпінь: Акад. ДПС України, 2001. 85 с.

3. Лукашев О. Владно-майнова природа фінансово-правових відносин. Вісник Академії правових наук України. Харків: Право, 2009. № 3 (58). C. 185-191.

DOI https://doi.org/10.30525/978-9934-26-074-2-30

\section{GROUNDS OF ADMINISTRATIVE LIABILITY FOR INTELLECTUAL PROPERTY OFFENSES}

\author{
Gerasimenko O. O. \\ orcid.org/0000-0002-2504-0637 \\ Postgraduate Student at the Administrative, \\ Financial and Information Law Department \\ Kyiv National University of Trade and Economics \\ Kyiv, Ukraine
}

The domestic theory on administrative law currently does not form unanimous opinion as for the grounds of administrative liability. Modern scientific views on the nature, typology, structure, content and relationship differ significantly (in some cases - dramatically). At times, such a wide pluralism of scientific opinions served as a positive factor, which gave impetus to active scientific discussion and significantly expanded the boundaries of the idea as for the grounds of administrative liability and their role in application of administrative delict rules. However, over time, the situation began to require reassessment. The main task of scientific discussions, that is the 118 
construction of coherent, generally accepted concept designed to serve as the basis for further scientific research, has not been achieved. Because of the absence of a single theoretical foundation, the author's views on the essence of the grounds of administrative responsibility instead of gradual approach are gradually moving away from each other, increasing the number of fundamental differences and creating confusion in terminology. The outlined tendencies contradict the objective demands of science and practice for maximum clarity and coherence of the conceptual and categorical apparatus. Having enlighted the above mentioned, the necessity of generalized relevant theoretical workouts and developed foundations, coherent approach to understanding the grounds of administrative liability emerges over.

It is worth to be noted, that despite unquestioning importance of the grounds for administrative liability, their essence evidently has not been disclosed within domestic administrative legislation. The corresponding term is mentioned in the Part 1 of Art. 7 of the Code of Ukraine on Administrative Offenses (hereinafter - CUoAO): «No one may be subjected to a measure of influence in connection with administrative offense other than on the grounds and in the manner prescribed by law,» as well as in the Part 1 of Art. 8 of the CUoAO, according to which: «A person who has committed an administrative offense is liable under the law, that is being in force at the time and place of the offense» [1]. However, these legislative provisions are hardly to be considered informative. On their grounds it is impossible to build a holistic view of nature, content, character and type of the grounds for administrative liability [2].

By and large, Articles 7 and 8 of the CUoAO reflect only some certain characteristics of the grounds for administrative liability. In particular, from the content of the Part 1 of Art. 7 follows the multiplicity of such grounds, as well as their obligation to apply administrative sanctions to a particular person. In its turn, the Part 1 of Art. 8 of the CUoAO contains the thesis that one of the grounds for administrative liability is the law, being in force at the time of the offense committed. Therefore, the legislative description of the grounds for administrative liability is characterized by its fragmentation and incompleteness.

On the background of legislative uncertainty, the issue of constructing a doctrinal concept of the grounds for administrative liability, capable of filling gaps in legislation and suitable for practical application, is becoming extremely acute. For many years in a row, this issue has attracted the attention of sectoral experts who have been trying to clarify nature and content of the grounds for administrative liability, determining their typology, systematizing their features, formulating the definition of the concept [3]. However, despite all efforts in this direction, the representatives of the branch science have not yet developed a unified, coordinated approach to understanding the grounds 
for administrative liability. Moreover, in modern scientific literature there can be found a number of different concepts, in which there are fundamentally different views as for the grounds of administrative liability, in particular, their quantity, essence, role within law enforcement $[4$, p. $57 ; 5$, p. 182; 6, p. 178; 7, p. 102; 8, p. p. 448-449; 9, p. p. 218-219; 10, p. p. 135, 136; 11, p. 30].

The analysis of modern approaches to understanding the grounds of administrative liability leaves double impression. On one hand, they represent individual, author's view on the grounds of administrative responsibility, and also serve as contribution to the development of scientific discussion about their nature and essence. On the other hand, they provide for excessive «fragmentation» of such grounds, giving an independent role to any factors influencing the implementation of administrative liability (guilt, material norm, etc.), even if they are being a part of the grounds of higher order (actual, normative, regulatory, jurisdictional). Such a fragmentation does not contribute to the formation of unanimous universal approach to understanding the grounds of administrative liability, which is much needed by the modern doctrine of administrative delict law. Therefore, paying a tribute to modern scientists in terms of the desire for comprehensive analysis of relevant issues, we should note that in the current environment, the appropriate direction of scientific research is not being manifested as construction of completely original concepts, but the development and unification of existing theoretical workouts.

From the point of view of compliance with theoretical principles and practical aspects on application of administrative delict rules, the most reasonable and universal seems to be three-element classification for the grounds for administrative liability, according to which they are as follows: actual unlawful encroachment (factual grounds); set of legal norms that regulate material and procedural aspects of administrative liability (regulatory grounds); official decision within relevant case (jurisdictional grounds).

Basing on this approach, as well as taking into account the above definitions of factual, regulatory and jurisdictional grounds of administrative liability, the foundations for administrative liability in the field of intellectual property are proposed to mean:

the fact of committing socially dangerous act, which has some features of the administrative offenses under Articles 51-2, 164-6, 164-7, 164-9, 164-13, 164-17, 164-18 and 186-7 of the CUoAO;

set of legal norms on the basis of which the qualification of a specific administrative offense in the field of intellectual property, procedural consideration and resolution of the offense case, as well as the implementation of decision taken in for this case; 
resolution on the imposition of administrative penalty or the application of measures of influence provided for by the Art. 24-1 of the CUoAO, onto a person who has committed an offense in the field of intellectual property.

\section{References:}

1. Кодекс України про адміністративні правопорушення. Biдомості Верховної Ради УРСР. 1984. № 51. Ст. 1122.

2. Гуржій Т.О. Правове регулювання адміністративноделіктних відносин: перспективи розвитку. Вісник Прокуратури. 2008. № 3. С. 103-116.

3. Гуржій Т.О. Нормативна регламентація адміністративної відповідальності водіїв за порушення Правил дорожнього руху. Вісник Прокуратури. 2007. № 7. С. 109-112.

4. Гуржій А. В. Адміністративна відповідальність за порушення правил дорожнього перевезення небезпечних вантажів та проїзду великогабаритних і великовагових транспортних засобів : дис. ... канд. юрид. наук : 12.00.07. Київ, 2013. 210 с.

5. Гуржій А. В. Підстави адміністративної відповідальності за порушення правил перевезення небезпечних, великоваговагових i великогабаритних вантажів. Наука $i$ правоохорона. 2012. № 1. C. 181-188.

6. Поштаренко О.В. Поняття, сутність та зміст адміністративної відповідальності в умовах нової парадигми адміністративного права. Адміністративне право і процес. 2020. № 3. С. 174-179.

7. Щербина С. М. К Поняття та ознаки громадського благоустрою як об’єкта адміністративного правопорушення. Право $i$ cycniльство. 2013. № 2. С. 102-106.

8. Цюприк Н.О. Принципи та підстави притягнення до адміністративної відповідальності працівників органів внутрішніх справ. Альманах права. 2012. Вип. 3. С. 448-452.

9. Цюприк Н.О. Принципи та підстави притягнення до адміністративної відповідальності працівників органів внутрішніх справ. Митна справа. 2014. № 3(2). С. 217-221.

10. Адміністративне право України / [Коломоєць Т. О., Ващенко С. В., Поліщук В. Г.] ; За ред.. Т. О. Коломоєць. - К. : Істина, 2008. -457 c.

11. Адміністративна відповідальність / І. Л. Бородін, В. А. Бортник. К.: ДП «Вид. дім «Персонал», 2011. 136 с. 